\title{
Outsourcing and skill-specific employment in a small economy: Austria after the fall of the Iron Curtain
}

\author{
Egger, H ; Egger, $\mathrm{P}$
}

\begin{abstract}
We set up a model, in which firms in a small industrialized country outsource part of their production to a foreign economy, which is rich in low-skilled labour. We analyse, how a decline in trade costs affects outsourcing activities and the production structure in the small economy. A stimulation of cross-border outsourcing raises wage dispersion and, if labour markets are unionized, also the employment of high-skilled relative to low-skilled labour. Using a panel of Austrian industries, we find, first, that decreasing trade barriers - as observed after the fall of the Iron Curtain - indeed stimulate outsourcing to Central and Eastern Europe and the former Soviet Union, and, second, that outsourcing to these countries significantly shifts relative employment in favour of high-skilled labour.
\end{abstract}

DOI: https://doi.org/10.1093/oep/55.4.625

Posted at the Zurich Open Repository and Archive, University of Zurich ZORA URL: https://doi.org/10.5167/uzh-2287

Journal Article

Published Version

Originally published at:

Egger, H; Egger, P (2003). Outsourcing and skill-specific employment in a small economy: Austria after the fall of the Iron Curtain. Oxford Economic Papers, 55(4):625-643.

DOI: https://doi.org/10.1093/oep/55.4.625 
All rights reserved

\title{
Outsourcing and skill-specific employment in a small economy: Austria after the fall of the Iron Curtain
}

\author{
By Hartmut Egger ${ }^{\star}$ and Peter Egger $\uparrow$
}

${ }^{\star}$ University of Zurich, Socioeconomic Institute, Department of Public Finance and Macroeconomics, Zürichbergstrasse 14, CH-8032 Zurich, Switzerland $\dagger$ University of Innsbruck, Department of Economics, Universitaetsstrasse 15, A-6020 Innsbruck, Austria; and Austrian Institute of Economic Research, P.O. Box 91, A-1103 Vienna, Austria; e-mail: Peter.Egger@uibk.ac.at

\begin{abstract}
We set up a model, in which firms in a small industrialized country outsource part of their production to a foreign economy, which is rich in low-skilled labour. We analyse, how a decline in trade costs affects outsourcing activities and the production structure in the small economy. A stimulation of cross-border outsourcing raises wage dispersion and, if labour markets are unionized, also the employment of high-skilled relative to low-skilled labour. Using a panel of Austrian industries, we find, first, that decreasing trade barriers-as observed after the fall of the Iron Curtain-indeed stimulate outsourcing to Central and Eastern Europe and the former Soviet Union, and, second, that outsourcing to these countries significantly shifts relative employment in favour of high-skilled labour.
\end{abstract}

\section{Introduction}

Cross border outsourcing is an essential characteristics of the current wave of globalization. Recent studies point to an important role of outsourcing and trade in intermediate inputs for the explanation of rising wage differentials in the US. Feenstra and Hanson (2001, p.1) stress that 'trade in intermediate inputs can have an impact on wages and employment that is much greater than for trade in final consumer goods' and Krugman (1995, p.331) remarks that 'it is hard to argue that the sheer volume of trade... marks a qualitative difference from previous experience'. Rather, it is the composition of trade in general and the share of intermediate goods in particular, which matters (Feenstra and Hanson, 2001, p.5).

Theoretical research on international outsourcing and its impact on factor prices predominantly builds upon traditional trade models. For an analysis in the Heckscher-Ohlin framework see Arndt (1997), Deardorff (2001), Egger (2002), Jones (2000), and Jones and Kierzkowski (1990, 2001). Kohler (2001) addresses the impact of outsourcing on the labour market in a specific factors model. The main finding is that the impact of international outsourcing on factor prices 
may be similar to the impact of sector-biased or factor-biased technological change, depending on the type of model used and the number of sectors engaged in international outsourcing (see the discussion in Egger and Falkinger, 2001). ${ }^{1}$ However, this literature does not consider imperfections in the factor markets, like the existence of institutions, so that the results are less important for unionized European labour markets, where the employment effects of cross-border outsourcing should be especially pronounced.

Empirical research on the impact of outsourcing on labour markets mainly focuses on the United States. Feenstra and Hanson $(1996,1997,1999)$ construct a wide measure of cross-border outsourcing and identify a pronounced effect on the US labour market in terms of high-skilled relative to low-skilled wages. In contrast, Slaughter (2000) concentrates on outsourcing by multinational enterprises headquartered in the US and does not find a significant impact. For European economies empirical findings are rather scarce. Egger and Egger (2001) concentrate on factor intensity changes in response to an increase in the EU's outward processing trade. Egger and Egger (2002) provide first insights into outsourcing induced factor price developments in Central and Eastern Europe. In Western European labour markets, employment effects of cross-border outsourcing should be especially relevant, due to the high degree of unionization. However, to our knowledge, evidence is missing so far.

We provide a theoretical model, in which firms in a small open economy (Home), which is a price-taker in the world market, may produce a homogeneous good either nationally, using low-skilled and high-skilled labour at home, or by outsourcing (part of) their intermediate input production across borders, using low-skilled labour abroad and only high-skilled labour at home. Cross-border outsourcing therefore leads to intermediate goods imports of Home. We investigate, how a decline in trade barriers affects outsourcing of firms located in Home into a foreign low-skilled labour rich economy (Foreign). We find that a stimulation of outsourcing activities raises the employment of high-skilled relative to low-skilled labour, if the market for low-skilled labour in Home is unionized.

In the econometric analysis, we examine the impact of trade liberalization between Western Europe and Eastern economies (including countries of Central and Eastern Europe and the former Soviet Union) observed after the fall of the Iron Curtain. In particular, we identify the effect of this trade liberalizing process on outsourcing activities and the related employment effects in Austria. Thereby, Austria seems to be a natural candidate due to the geographical proximity and historic ties to the Eastern economies. ${ }^{2}$ In the manufacturing sector outsourcing to Eastern countries rose dramatically during the period 1990-1998. With an average

\footnotetext{
${ }^{1}$ For a discussion on whether it is the factor bias or the sector bias of technological change, which matters for the relative factor price adjustments, see Krugman (2000) and Leamer (1998).

${ }^{2}$ In 1997, Austria's imports of manufactures from Central and Eastern Europe and the former Soviet Union relative to gross production were 2.5 times higher than the EU average (calculations are based on OECD Statistics on Foreign Trade).
} 
annual increase of $10.71 \%$, it grew much faster than overall outsourcing $(1.67 \%$ p.a.), exports (3.9\% p.a.), or imports (2.8\% p.a.). ${ }^{3}$ In the Austrian labour market, the ratio of high-skilled relative to low-skilled employment rose markedly, with an average annual growth rate of $4.43 \%$. In contrast, the ratio of high-skilled relative to low-skilled wages was nearly constant over the same period with an average annual growth rate of $0.02 \%$. This asymmetry in relative employment and relative wage dynamics may be explained by the high degree of unionization in Austrian labour markets, with the highest bargaining coverage rate of all EU members.

We find our theoretical predictions to be widely in accordance with the empirical results for a panel of 20 manufacturing industries at the NACE 2-digit level. First, outsourcing to Eastern countries is low-wage seeking and stimulated by shrinking trade barriers. Second, an increase in outsourcing to the Eastern countries by $1 \%$ shifts relative employment by about $0.1 \%$ in favour of high-skilled labour. We apply two panel econometric approaches, instrumental variables (two-stage least squares, 2SLS, see Krishnakumar, 1996) and systems estimation (three-stage least squares, 3SLS) techniques using a fixed (industry and time) effects estimator. According to our results, outsourcing has to be treated as an endogenous variable. Otherwise, there would be a downward bias of the outsourcing effects on relative employment.

The paper is organized as follows. Section 2 introduces the theoretical model, Section 3 presents the empirical results. Section 4 provides some concluding remarks. In the Appendix, details on the construction and data sources of variables are provided.

\section{Theoretical framework}

An industrialized economy 'Home', endowed with $\bar{H}$ units of high-skilled and $\bar{L}$ units of low-skilled labour, faces two potential trading partners, 'Foreign' and an unspecified Rest of the World ('RoW'). ${ }^{4}$ We assume that Home is small as compared to RoW and, in addition, that Home's demand for low-skilled labour is low relative to Foreign's low-skilled labour supply. Trade between Home and RoW is free, whereas tariffs and non-tariff barriers are an important impediment to trade between Foreign and Home as well as between Foreign and RoW.

Competitive firms in Home employ high-skilled and low-skilled labour in the production of a single homogeneous final good $X$ (the numéraire good). Markets for the two skill groups are segmented and both $H$ and $L$ are internationally immobile. Whereas high-skilled labour is supplied in a perfectly competitive labour market in Home, trade union activities may play an important role in determining both the employment level and the wage rate of low-skilled labour.

\footnotetext{
${ }^{3}$ Noteworthy, outsourcing to OECD countries increased only by $0.6 \%$ p.a.

${ }^{4}$ Home may be associated with Austria and Foreign represents Central and Eastern Europe and the former Soviet Union.
} 
In our theoretical analysis, we allow for unionized as well as competitive low-skilled labour markets and compare our findings for these two labour market regimes. Motivated by the empirical observation that relative wages are not fully flexible in a unionized economy (see e.g. Belman and Heywood, 1990; Meng, 1990; and Dell'Aringa and Lucifora, 1994), we assume that the wage-setting curve, which represents the outcome of the wage determination process in a unionized labour market, gives a negative relationship between low-skilled labour employment and relative wages (measured as wages of high-skilled relative to lowskilled labour). ${ }^{5}$ As in right-to-manage and monopoly union models, firms choose employment unilaterally so that low-skilled labour is paid its marginal product.

There are two technologies available in Home to produce the homogeneous final good $X$ : an integrated production mode $(i)$ and a fragmented one $(f)$. Whereas integrated production, which is assumed to be organized within a single firm, is entirely located in Home and uses both low-skilled and high-skilled labour supplied by Home, a fragmented firm produces only a down-stream fragment in Home, while it imports an up-stream component from Foreign. Cross-border outsourcing is attractive, since low-skilled labour is cheaper in Foreign than it is in Home. ${ }^{6}$ For the sake of simplicity, we assume that differences in wage rates are too small to pay for outsourcing activities between Home and RoW so that outsourcing (for both Home and RoW) is only possible to Foreign. Thus, Home exports $X$ and imports intermediate goods from Foreign. We assume that the imported intermediate good is produced by a foreign affiliate of a multinational enterprise located in Home. The down-stream process uses only high-skilled labour together with the imported fragment. In the production of the up-stream fragment, Foreign's low-skilled labour is employed. Moreover, some additional high-skilled labour supplied by Home is necessary to make Foreign's intermediate good usable for Home. ${ }^{7}$ In sum, fragmented production $(f)$ does not use Home-supplied low-skilled labour.

In Section 2.1 we derive the equilibrium values for outsourcing activities, wages, and employment as functions of the economic fundamentals of Home, low-skilled wages in Foreign, and trade costs for intermediate inputs. Section 2.2 provides a comparative static analysis for the impact of a decline in trade costs on outsourcing, wages, and employment.

\footnotetext{
${ }^{5}$ The idea is that unions attempt to reduce the spread between high-skilled and low-skilled wages and accept a higher wage dispersion only, if low-skilled labour employment declines, i.e., if unemployment of the low-skilled workers increases.

${ }^{6}$ Grossman and Helpman (2002) stress the importance of imperfect contracting and search costs in the context of fragmentation. This issue is not considered here

${ }^{7}$ Jones (2000, p.117) stresses the importance of service links for cross-border outsourcing. 'The costs of service links include...costs of communication, and the costs of planning and the coordination to match the quality and quantity of output flows'. In Burda and Dluhosch (2002), expenditures for business service activities determine the degree of fragmentation.
} 
2.1 Production technologies, profit maximization and outsourcing equilibrium

The two production technologies are given by

$$
\begin{aligned}
& X_{k}^{i}=F^{i}\left(l_{k}, h_{k}^{i}\right) \\
& X_{j}^{f}=F^{f}\left(o_{j}, h_{j}^{d}\right)
\end{aligned}
$$

where superscript $i(f)$ indicates that the production of firm $k(j)$ is integrated (fragmented). $X_{k}^{i}$ and $X_{j}^{f}$ denote output. $l_{k}$ is low-skilled labour from Home employed in firm $k . h_{k}^{i}$ is high-skilled labour from Home employed in integrated firm $k . h_{j}^{d}$ is high-skilled labour from Home employed in the down-stream process of a fragmented firm $j$ ( $d$ refers to the down-stream process). $F^{i}(\cdot)$ and $F^{f}(\cdot)$ are linearly homogeneous, strictly increasing, and strictly quasiconcave production functions. $o_{j}$ is the intermediate input of firm $j$, produced in Foreign by an affiliate of multinational firm $j$ under a Leontief technology

$$
o_{j}=\min \left\{\hat{l}_{j}, h_{j}^{u}\right\}
$$

where $\hat{l}_{j}$ denotes Foreign low-skilled labour used to produce the imported fragment $o_{j} . h_{j}^{u}$ units of high-skilled labour are necessary for coordination activities to make $o_{j}$ units of Foreign's intermediate good usable in the downstream process of a fragmented firm in Home. $u$ indicates the up-stream process. This (Homesupplied) high-skilled labour, $h_{j}^{u}$, employed in the production of the up-stream fragment, cannot be substituted by Foreign-supplied low-skilled labour $\hat{l}_{j}$. According to (1), (2), and (3), Home's high-skilled labour can be employed either in an integrated firm $\left(h^{i}\right)$, in the down-stream process of a fragmented firm $\left(h^{d}\right)$, or in the production of the imported intermediate good $\left(h^{u}\right)$.

The decision problem of integrated firm $k$ is given by

$$
\max _{l_{k}, h_{k}^{i}} F^{i}\left(l_{k}, h_{k}^{i}\right)-w_{L} l_{k}-w_{H} h_{k}^{i}
$$

where $w_{L}$ and $w_{H}$ denote wage rates of (Home-supplied) low-skilled and highskilled labour, respectively. Individual firms take wages as given. The decision problem of outsourcing firm $j$ is

$$
\max _{o_{j}, h_{j}^{d}} F^{f}\left(o_{j}, h_{j}^{d}\right)-\left[w_{\hat{L}}+w_{H}+t+\tau(O)\right] o_{j}-w_{H} h_{j}^{d}
$$

$w_{\hat{L}}$ denotes Foreign's wage rate for low-skilled labour and $t$ represents trade costs (tariff or non-tariff barriers to trade). $O \equiv \sum_{j=1}^{J} o_{j}$ is Home's aggregate outsourcing volume. $\tau(O)$ indicates the possibility of external diseconomies of scale and accounts for possible limitations of outsourcing. External diseconomies of scale may arise due to congestion at the border, rising prices for buildings and offices in Foreign, or other variable infrastructure costs. We assume $\tau(0)=0$ and $\tau^{\prime}(O) \geq 0$. 
Two cases are considered: (i) for all $O \tau^{\prime}(O)>0$, implying external diseconomies of scale and (ii) for all $O \tau^{\prime}(O)=0$, where diseconomies of scale do not arise, since $\tau(O)=0$ holds for all $O$.

We focus on interior solutions i.e., $l_{k}>0, h_{k}^{i}>0, o_{j}>0$ and $h_{j}^{d}>0 .{ }^{8}$ We denote the respective aggregate employment levels in integrated firms by $L$ and $H^{i}$, and the aggregate employment levels in fragmented firms by $H^{u}$ and $H^{d}$. Subscript notation is used for partial derivatives. Then, due to the linear homogeneity of the production functions, the first-order conditions for optimal factor inputs in integrated firms are

$$
\begin{aligned}
F_{L}^{i}(1, \kappa) & =w_{L} \\
F_{H^{i}}^{i}(1, \kappa) & =w_{H}
\end{aligned}
$$

with $\kappa \equiv H^{i} / L$. The first-order conditions for optimal input choice in fragmented firms are

$$
\begin{aligned}
& F_{O}^{f}(1, v)=\hat{c}+w_{H}+\tau(O) \\
& F_{H^{d}}^{f}(1, v)=w_{H}
\end{aligned}
$$

where $v \equiv H^{d} / O$ and $\hat{c} \equiv w_{\hat{L}}+t$. Since aggregate demand for high-skilled labour is given by $H^{i}+H^{u}+H^{d}$, the aggregate resource constraint for high-skilled labour is

$$
\kappa L+(1+v) O=\bar{H}
$$

If relative wages are fully flexible, i.e., in the case of a competitive low-skilled labour market, equilibrium employment of low-skilled labour is given by

$$
L=\bar{L}
$$

In contrast, in the presence of trade unions employment is a negative function of relative wages, i.e.

$$
L=L(\omega), \quad L^{\prime}(\omega)<0
$$

with $\omega \equiv w_{H} / w_{L} . L(\omega)$ is the wage-setting curve that gives all possible $(L, \omega)$ combinations, which are consistent with the wage determination process in a unionized low-skilled labour market. ${ }^{9}$

The system of the six eqs (6)-(10) and (11a) or (11b) determines the equilibrium values of $w_{L}, w_{H}, \kappa, v, L$ and $O$ as functions of costs $\hat{c}$, technologies $F^{i}, F^{f}, \tau$, highskilled labour endowment $\bar{H}$, and low-skilled labour endowment $\bar{L}$ in the case of a competitive low-skilled labour market, or $L(\omega)$ in the presence of unions. Note that zero-profit conditions $\pi^{i}=0$ and $\pi^{f}=0$ are always fulfilled in equilibrium due to the linear homogeneity of $F^{i}$ and $F^{f}$.

${ }^{8}$ This means that trade barriers $t$ and low-skilled wages in Foreign $w_{\hat{L}}$ are such that they allow for some outsourcing from Home into Foreign but not for full specialization in the fragmented production mode.

${ }^{9}$ We assume that $L(\omega)$ is such that an interior solution with both production technologies used in equilibrium is guaranteed. 


\subsection{Comparative static analysis: a decline in trade barriers $t$}

How does a decline in trade barriers $t$ (as observed in the period after the fall of the Iron Curtain) affect equilibrium values of outsourcing activities, relative wages and relative labour employment in Home? Note first, that eqs (6) and (7) give the standard negative relationship $\kappa(\omega), \kappa^{\prime}(\omega)<0$ (with inverse $\omega(\kappa), \omega^{\prime}(\kappa)<0$ ), where $\omega=w_{H} / w_{L}$ is the relative wage. Second, eqs (7) and (9) establish a monotonous relationship $v(\kappa), v^{\prime}(\kappa)>0$ between skill-intensity $\kappa$ in integrated production and skill-intensity $v$ in fragmented production. Third, using $v(\kappa)$, $v^{\prime}(\kappa)>0, \omega(\kappa), \omega^{\prime}(\kappa)<0$, implicit differentiation of resource constraint (10) gives a negative relationship $O(\kappa), O^{\prime}(\kappa)<0$ between outsourcing volume $O$ and skill-intensity $\kappa$. (Note $d L / d \kappa=L^{\prime}(\omega) \omega^{\prime}(\kappa) \geq 0$, since $L^{\prime}(\omega) \leq 0$, according to (11a), (11b).) Finally, we substitute (9) for $w_{H}$ in (8) to obtain

$$
F_{O}^{f}(1, v(\kappa))-F_{H^{d}}^{f}(1, v(\kappa))=\hat{c}+\tau(O(\kappa))
$$

$F_{O H^{d}}^{f} \geqslant 0, F_{H^{d} H^{d}}^{f}<0$ and $v^{\prime}(\kappa)>0$ imply that the left-hand side of (12) increases with $\kappa$, whereas the right-hand side is non-increasing in $\kappa$ because of $\tau^{\prime}(O) \geqslant 0$ and $O^{\prime}(\kappa)<0$. Thus, (12) determines a positive relationship $\kappa(\hat{c}), \kappa^{\prime}(\hat{c})>0$. Note that all results so far are independent of the labour market regime, i.e., independent of whether the low-skilled labour market is competitive or unionized. Relationship $\kappa(\hat{c})$ allows us to derive the comparative static effects of a decline in trade barriers $t$. Since Home's demand for low-skilled labour is assumed to be small with respect to the low-skilled labour supply in Foreign, $w_{\hat{L}}$ is exogenous from Home's point of view. ${ }^{10}$ Equations (10) and (12) determine the equilibrium values $\kappa^{*}$ and $O^{*}$.

As a first result, we find that $d O^{*} / d t<0$. This is an immediate consequence of $\kappa^{\prime}(\hat{c})>0$ and $O^{\prime}(\kappa)<0$. Thus, a decline in trade barriers $t$ implies a decrease in skill-intensity $\kappa$ and an increase in outsourcing activities $O$, and therefore a shift from integrated to fragmented production in Home. ${ }^{11}$ This outcome is independent of the labour market regime. Second, if the low-skilled labour market is competitive, relative wages $\omega^{*}$ increase in equilibrium. Third, according to (10), if the low-skilled labour market is unionized so that $L<\bar{L}$ in equilibrium, the level of outsourcing $O$ is relatively higher than in a competitive labour market, ceteris paribus. According to (12), this has no consequence for skill-intensity $\kappa$ and relative wages $\omega$ in the case of $\tau=0$. However, if $\tau^{\prime}>0$, then a relatively higher volume of $O$ implies a relatively higher value of $\kappa$ and thus a lower value of $\omega$. In sum, with a unionized low-skilled labour market we have two cases: (i) without $O$-costs

\footnotetext{
${ }^{10}$ In the case of Central and Eastern Europe and the former Soviet Union, the decline in trade barriers vis-à-vis Austria was accompanied by a decline in trade barriers vis-à-vis all other members of the European Union. The latter may imply an adjustment of Foreign's factor prices, i.e., an increase in low-skilled wages $w_{\hat{L}}$, if trade barriers decline. However, even if the decline in $t$ goes hand in hand with a decline in trade barriers between Foreign and the RoW, our results remain valid as long as the opening up of Foreign is 'effective' from Home's point of view, which is the case, if $\hat{c}$ declines.

${ }^{11}$ For a similar finding see Jones and Kierzowski (1990) and Egger and Falkinger (2001). See also Feenstra (1998) and Krugman (1995).
} 
(i.e., $\tau=0$ ), skill-intensity $\kappa$ and relative wages $\omega$ resulting under a unionized lowskilled labour market regime are the same as in competitive labour markets, but the level of outsourcing $O$ is higher. In this case unions do not succeed in moderating the increase in $\omega$ following a decline in trade barriers. In other words, the whole effect of the opening up is absorbed by a decline in $L$, i.e., an increase in $\bar{H} / L$, which induces trade unions to tolerate the high $\omega$. (ii) If $\tau^{\prime}>0$, unions succeed in moderating the rise in $\omega$. Ceteris paribus, $L$ declines less and a lower outsourcing volume $O$ results.

In the empirical analysis below, we assess the role of tariff and non-tariff barriers to trade as well as of foreign wages for Austrian outsourcing to Central and Eastern Europe and the former Soviet Union. Furthermore, we investigate the consequences of a change of outsourcing to the Eastern economies for high-skilled relative to low-skilled labour employment in Austrian manufacturing.

\section{Empirical analysis}

We use a small panel of 20 Austrian NACE 2-digit industries over the period 19901998. In the Appendix, we provide details on the construction of variables and data sources. The empirical analysis proceeds in two steps. First, we assess the determinants of Austrian outsourcing to Eastern countries. From our theoretical model, we expect that the decline in trade costs (tariff and non-tariff barriers to trade) after the fall of the Iron Curtain has raised outsourcing of Austrian firms to the Eastern economies. Besides trade costs, wage costs in the Eastern economies should be relevant, according to our theoretical analysis. To control for all other industryspecific determinants such as persistent technological differences and all timespecific determinants such as the business cycle or the decline in information and telecomunication costs, we use a fixed industry and time effects estimator. Second, we try to identify the effect of outsourcing on the employment of highskilled relative to low-skilled labour. Thereby, we control for other channels of influence like relative wages, exports, imports, and capital intensity. Again, we include fixed industry and time effects to guard against omitted variables in the respective dimensions. Since both relative employment and relative wages are simultaneously determined, there is an inherent problem of endogenous wages, which motivates an instrumental variable approach. Additionally, our theoretical model illustrates the endogeneity of outsourcing, which has so far not been considered in the empirical literature. We use the mentioned determinants of outsourcing, the degree of trade union organization $(O R G)$, the industry price-cost margin (PCM) and medium firm size (MSIZE) as instruments. ${ }^{12} \mathrm{We}$ apply a traditional two-stage least squares and a three-stage least squares fixed

${ }^{12}$ Whereas the determinants of outsourcing (tariff barriers, TB, non-tariff barriers, NTBD and NTBI, and unit labour costs in Eastern Europe, ULCE) and $O R G$ are motivated in our theoretical analysis, we include PCM and MSIZE following previous empirical research. For further details, see the data description in the Appendix. 
effects estimator. In the former, we once treat outsourcing as endogenous and once as exogenous to show that an exogenous treatment of outsourcing results in biased parameters. Thereby, we use the same instruments for both relative wages and endogenous outsourcing. The three-stage least squares estimator has two advantages: (i) it allows for different sets of instruments for relative wages and outsourcing, and (ii) it results in more efficient parameter estimates. Using the same set of instruments as the two-stage least squares model identifies the pure efficiency gain of three-stage least squares. The second approach of different sets of instruments for relative wages (ORG, PCM, MSIZE) and outsourcing (TB, NTBD, $N T B I, U L C E)$ is closer to our theoretical model.

\subsection{Determinants of outsourcing}

Table 1 reports results of fixed effects panel regressions of outsourcing on the weighted average of Eastern unit labour costs (ULCE), trade barriers (TB), and the two non-tariff barriers to trade variables as introduced in the Appendix $(N T B D, N T B I) .{ }^{13}$

Specification I assesses the determinants of outsourcing to the Eastern economies relative to gross production $(O Y)$, and Specification II of outsourcing to the Eastern economies relative to overall intermediate goods purchases $(O I)$. The results broadly confirm our view that outsourcing to Eastern countries is lowcost seeking, reflected by a negative parameter of ULCE. The reduction in tariff

Table 1 The determinants of Austrian outsourcing into Eastern economies (1990-1998)

\begin{tabular}{|c|c|c|c|c|}
\hline \multirow[b]{2}{*}{ Dependent variable } & \multicolumn{2}{|c|}{ Specification $I^{\S)}$} & \multicolumn{2}{|c|}{ Specification II $\left.^{+}\right)$} \\
\hline & $\boldsymbol{\beta}$ & Std. error & $\boldsymbol{\beta}$ & Std. error \\
\hline $\begin{array}{l}\text { Unit labor costs in Eastern } \\
\text { countries (ULCE) }\end{array}$ & -0.89 & $0.313^{* *)}$ & -0.83 & $\left.0.294^{* *}\right)$ \\
\hline Tariff barriers (TB) & -0.43 & $\left.0.124^{* *}\right)$ & -0.41 & $\left.0.122^{* *}\right)$ \\
\hline Non-tariff barriers dummy (NTBD) & 0.60 & $\left.0.160^{* \star}\right)$ & 0.56 & $\left.0.158^{* *}\right)$ \\
\hline Non-tariff barriers interaction (NTBI) & -0.01 & 0.009 & -0.01 & 0.009 \\
\hline Constant & -6.70 & $0.598^{* *}$ & -6.03 & $\left.0.567^{* *}\right)$ \\
\hline Statistics $(\mathrm{N}=20 ; \mathrm{T}=9)$ & \multicolumn{2}{|c|}{ p-value } & \multicolumn{2}{|c|}{ p-value } \\
\hline Observations & 180 & & 180 & \\
\hline Adj. $R^{2}$ & 0.89 & & 0.89 & \\
\hline Time effects: $\left.F(8,148)^{*}\right)$ & 2.96 & $0.004^{* *}$ & 3.12 & $\left.0.003^{* *}\right)$ \\
\hline Industry effects: $F(19,148)^{\ddagger}$ & 66.92 & $0.000^{* *}$ & 62.09 & $\left.0.000^{* *}\right)$ \\
\hline
\end{tabular}

Notes: All variables are in logs. Parameter estimates for fixed time and industry effects are not reported in order to save space. Only heteroskedasticity consistent standard errors are reported.— ) Outsourcing to Eastern countries measured in \% of gross production.- $\dagger$ ) Outsourcing to Eastern countries measured in $\%$ of intermediate inputs.— $\ddagger$ ) Degrees of freedom in parentheses.-—*${ }^{\star *}$ ) significant at $5 \%,{ }^{*}$ ) significant at $10 \%$.

${ }^{13}$ See Görg (2000) for an assessment of the determinants of US inward processing trade with the EU. 
barriers $T B$, as observed after the fall of the Iron Curtain, has indeed led to an increase in Austrian outsourcing to Eastern economies. The positive sign of the $N T B D$ parameter squares with our theoretical prediction, but this variable has almost no variation in the time dimension. NTBI shows a negative but insignificant sign. The parameter estimate of NTBI captures the marginal impact of an increase in the frequency of NTBs on outsourcing. From a theoretical point of view, we would have expected a significant negative impact of NTBI.

\subsection{Employment effects of outsourcing}

The second step of our empirical analysis is concerned with the employment effects of outsourcing. We propose the following specification

$$
R S_{i t}=\beta_{0}+\beta_{1} R W_{i t}+\beta_{2} X Y_{i t}+\beta_{3} M Y_{i t}+\beta_{4} K Y_{i t}+\beta_{5} O U T_{i t}+\mu_{i}+\lambda_{t}+\varepsilon_{i t},
$$

where $R S$ is the employment of high-skilled labour relative to low-skilled labour $(H / L), R W$ is the relative wage rate $\left(w_{H} / w_{L}\right), X Y$ are exports relative to gross production (export openness), $M Y$ are world imports minus the volume of outsourcing to Eastern countries relative to gross production, $K Y$ is the capital-output ratio (real stock of capital relative to gross production), OUT is outsourcing to the Eastern economies (i.e., $O Y, O I$, respectively), and $\mu_{i}\left(\lambda_{t}\right)$ represents fixed industry (time) specific effects. As mentioned above, there is an econometric problem of endogeneity between relative employment $(R S)$ and relative wages $(R W)$ as well as between relative employment $(R S)$ and outsourcing $(O U T)$. Such endogeneity leads to biased and inconsistent estimates of the ordinary least squares parameters. Therefore, we have to use instrumental variables (IV), to obtain consistent estimates. Table 2 reports the results of applying IV for relative wages $(R W)$ as well as outsourcing (OUT) in Specifications 1 and 2, and for relative wages only (treating outsourcing as exogenous) in Specifications 3 and 4 . Note that we again distinguish between $O Y$ (Specifications 1 and 3) and $O I$ (Specifications 2 and 4). According to the normality tests, the database exhibits sound properties for the hypothesis tests. The reported Ramsey RESET tests confirm that there might be additional unexhausted information, which could be due to underlying non-linearities. We therefore should interpret the estimation results with care.

Outsourcing to Eastern countries $(O Y, O I)$ exerts a significant positive impact on the employment of high-skilled workers relative to low-skilled workers. This is a robust result, which does not depend on whether we treat outsourcing as exogenous (Specifications 3 and 4) or not (Specifications 1 and 2). The (negative) impact of relative wages on relative employment turns out to be insignificant. This does not mean that unions are not important in the wage-setting process, rather, the importance of unions is reflected by their significant impact on relative wages. All other explanatory variables enter significantly. Export openness and import openness are included to control for trade effects, which raise the efficiency of production (Greenaway et al., 1999). We find that an increase in Austrian industry 


\section{H. EGGER AND P. EGGER 635}

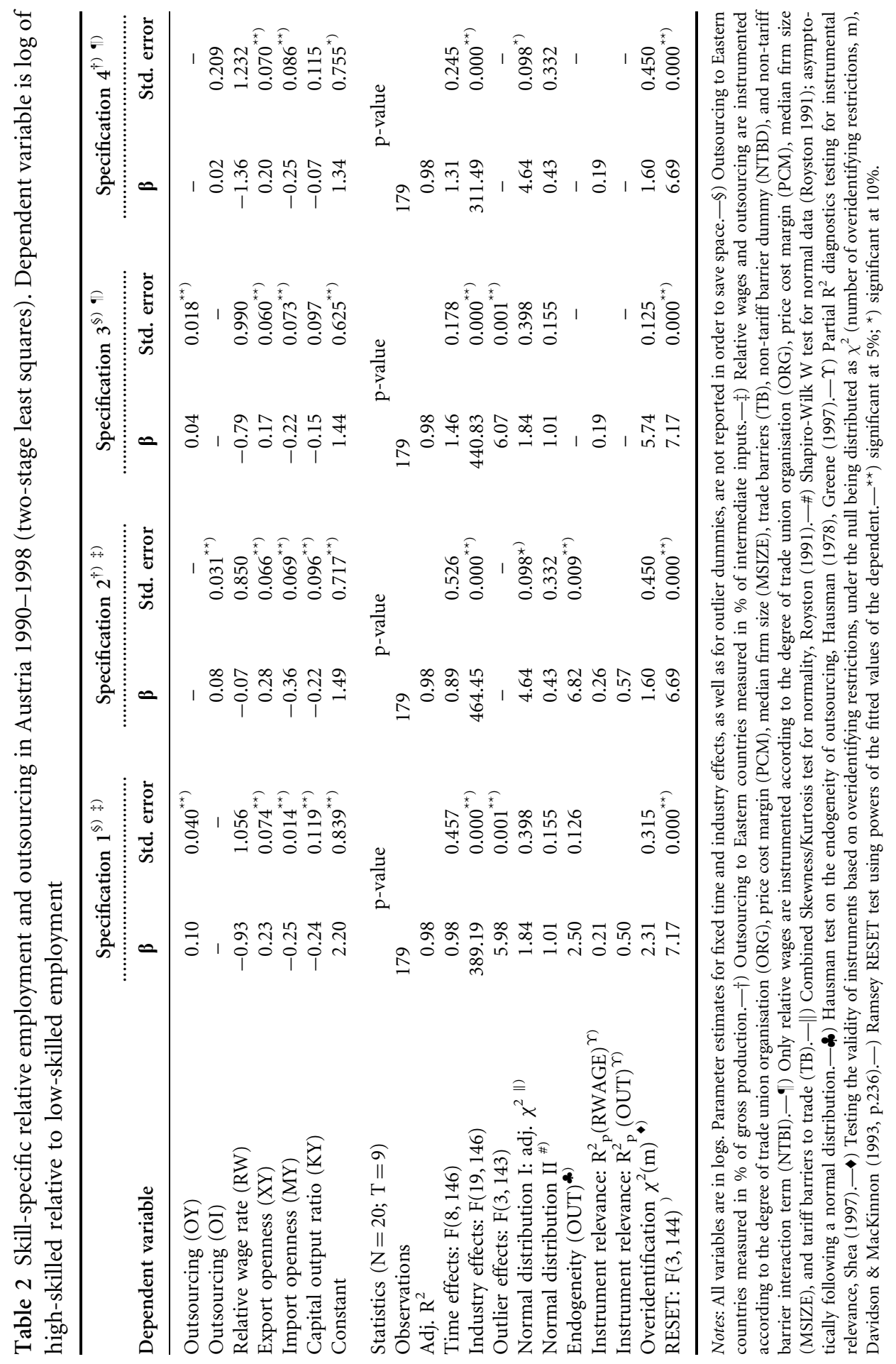


exports $(X Y)$ has an employment effect in favour of high-skilled workers. The opposite holds true for imports $(M Y)$, which exert a negative impact on relative employment. The latter is due to a displacement effect, since Austria is an importer of high-skilled labour intensive goods. This reduces the relative demand for domestic high-skilled employees. It is important to note that the effect of $M Y$ on relative labour employment is different from the effect of $O U T(O Y, O I)$. The main reason for this probably is that OUT only contains intermediate goods imports from low-skilled labour rich Eastern economies. In contrast, MY includes all imports minus outsourcing to Eastern countries, especially those from highly industrialized (Western European) countries. A higher capital intensity $(K Y)$ is associated with a lower ratio of high-skilled relative to low-skilled employment. At the Austrian industry level, we do not observe a high positive correlation between capital and high-skilled labour employment. This squares with evidence for the US (see Berman et al., 1994) and other countries and may be explained by the fact that a majority of the capital-intensive industries in Austria comprises large former stateowned enterprises, which are specialized in the production of low-skill-intensive goods. According to the F-tests, both fixed industry effects and outlier dummies contribute relevant information. Interestingly, this is not the case for overall exogenous, non-neutral technical change (fixed time effects).

Buse (1992) and Shea (1997) remark that the inclusion of irrelevant and overidentifying instruments increases the finite sample bias of the IV estimator. Therefore, in the IV two-stage least squares (2SLS) regressions only those instruments are used, which have a significant impact in the first stage regressions. These are the degree of union organization $(O R G)$, the price-cost margin $(P C M)$, median industry firm size (MSIZE), and the most favoured nation tariff rate $(T B)$ in all specifications. In Specifications 1 and 2, relative wages $(R W)$ and outsourcing (OY, OI) are instrumented with the same variables. We apply Shea's (1997) partial $R_{p}^{2}$ test in order to check for instrumental relevance. ${ }^{14}$ We find that instruments do have a relevant impact and that the instrumentation of outsourcing is of even greater relevance than that of relative wages. Additionally, we apply the Davidson and MacKinnon (1993) test on instrument validity. This is a specification test for the correlation of the instruments with the error term in the second stage regression. In our case, the test statistics do not reject the hypothesis of proper specification and instrumentation in any of the specifications of Table 2. We may therefore conclude from our analysis that outsourcing should be treated as endogenous in the empirical setup. Ignoring the possible endogeneity would result in a downward bias of the estimated effect of outsourcing on relative employment.

As is well known, the 2SLS estimator is consistent but only a limited information method. Therefore, this technique is less efficient than a systems estimator. In order to overcome this problem, one has to consider full information or systems methods

${ }^{14}$ Partial $R_{p}^{2}$ measures the additional contribution of the instrument set for the explanation of each endogenous variable. 
of estimation (e.g., three-stage least squares, 3SLS, or full information maximum likelihood estimation, FIML). From an econometric point of view, systems estimation also enables us to overcome another problem. In the presence of two or more endogenous variables (which is the case in our example), 2SLS only allows for a single set of instruments for the whole set of endogenous variables. This might provide less theoretical support than a distinct identification and it artificially causes problems of irrelevance in the presence of multicollinearity between parts of the sets of instruments, especially, if the instruments are not perfectly exogenous (Shea, 1997). ${ }^{15}$ The latter results in a finite sample bias of the estimator. We therefore estimate four specifications by 3SLS (see Table 3). Two of them use the same set of identifying variables for both relative wages and outsourcing (Specifications A and B) and are explicitly in accordance with Specifications 1 and 2 in Table 2. The remaining two specifications ( $C$ and D) distinguish between the set of identifying assumptions for relative wages (degree of organization of trade unions, ORG; medium industry firm size, MSIZE; and price-cost margin, $P C M$ ) and for outsourcing (tariff barriers, TB; non-tariff barriers, NTBD and NTBI; and unit labour costs in Eastern economies, ULCE).

As expected, there is only a minor difference between Specification A (B) and Specification 1 (2), which primarily shows up in lower standard errors and is due to the efficiency gain of 3SLS. Applying different sets of identifying assumptions for relative wages and outsourcing underpins the robustness of our results. The impact of outsourcing on relative employment is always significantly positive. Moreover, the effects are very close and a $1 \%$ increase in outsourcing to the Eastern economies leads to a change in relative employment of between $0.08 \%$ and $0.12 \% .{ }^{16}$ Over the last decade, we observe an increase in outsourcing to the Eastern economies of about $11 \%$ and an increase in relative employment of about $4.5 \%$ p.a. Thus, our econometric results would lead us to the conclusion that outsourcing to the Eastern countries accounts for about a quarter of the change in relative employment in favour of high-skilled labour.

\section{Concluding remarks}

The opening up of Central and Eastern Europe and the former Soviet Union after the fall of the Iron Curtain has induced a political and economic (re)orientation

\footnotetext{
${ }^{15}$ Shea (1997, p.348) notes for 2SLS that 'low relevance increases the inconsistency of IV estimates whenever instruments are not perfectly exogenous. Even when instruments are perfectly exogenous, low relevance increases asymptotic standard errors and therefore reduces the power of hypothesis tests. Moreover, low relevance can cause the finite-sample distribution of IV estimates to depart considerably from the asymptotic normal distribution... 2 The same, of course, holds true for 3SLS.

${ }^{16}$ Recall from the Appendix that $O Y$ is a composite of two effects, namely of a change in the share of Eastern countries in intermediate imports and a change in the share of intermediate goods in gross production. This measure might be superior for our purpose, particularly as compared to OI, which only reflects the change in the role of the Eastern countries in outsourcing relative to others (reflected by a lower coefficient of outsourcing in Specifications B and D as compared to A and C).
} 
638 OUTSOURCING AND SKILL-SPECIFIC EMPLOYMENT

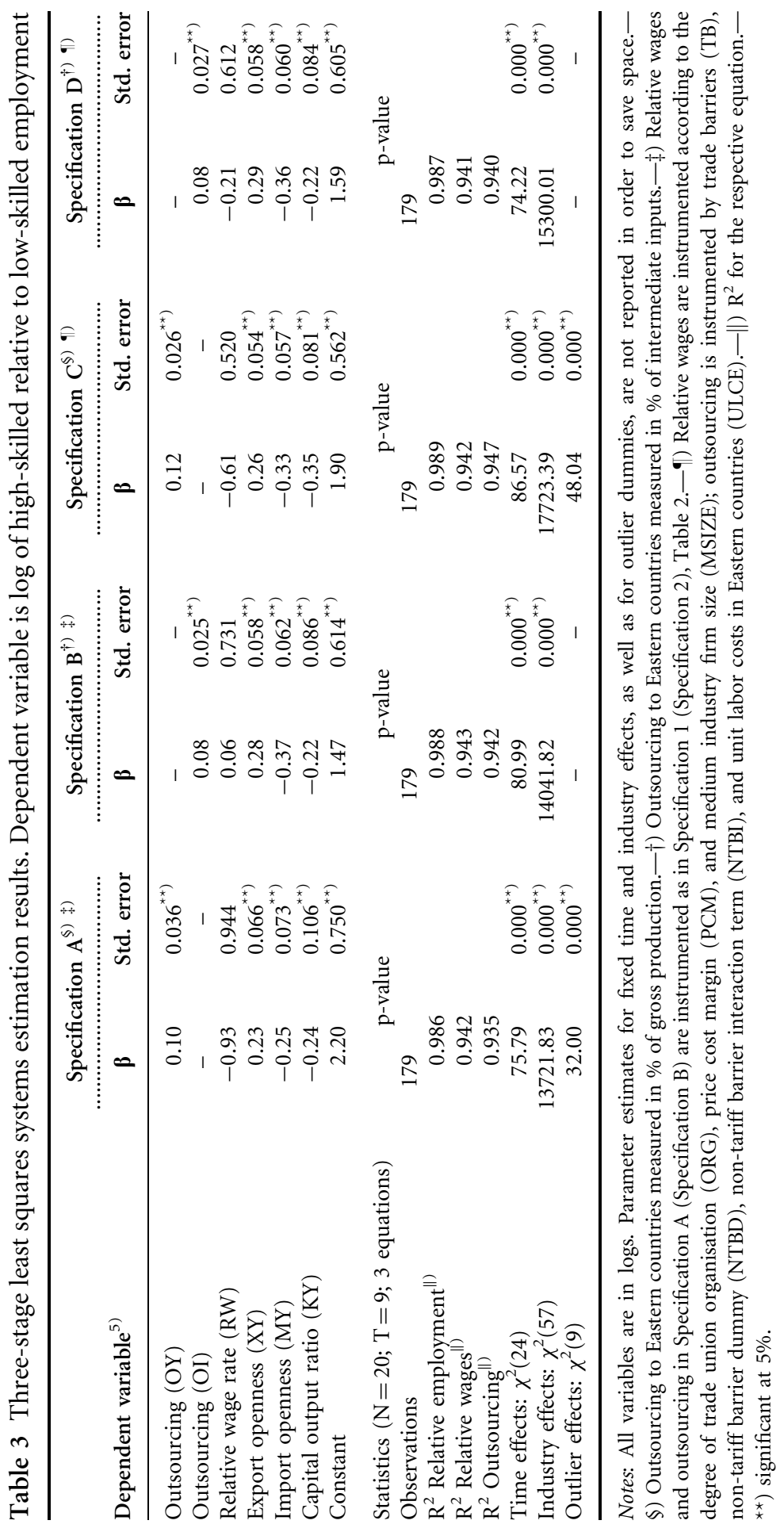


of these countries towards the EU at rather rapid pace. Especially, intermediate goods trade between Western European and Eastern economies has considerably increased in this period. This motivates the question about the causes of increased outsourcing to the low-wage Eastern countries and its consequences for the unionized labour markets in (small) Western European economies.

We present a model in which trade of a small country, Home, with Foreign (in our context to be associated with the Eastern economies) is impeded, while Home trades freely with the Rest of the World. We focus on a homogeneous industrialized good, which may be produced either nationally, using low-skilled and high-skilled labour at Home, or in a fragmented way by outsourcing across borders, using low-skilled labour abroad and only high-skilled labour at Home. Based on this framework, we investigate the impact of a decline in trade barriers on outsourcing of firms located in Home into low-skilled labour rich Foreign. In addition, we identify the effects of a stimulation of cross-border outsourcing on Home's labour markets. The main findings are the following. First, the volume of outsourcing increases if trade barriers decline. Second, if Home's labour markets are competitive, an increase in outsourcing raises relative wages in favour of high-skilled labour, but it has no impact on the employment of high-skilled relative to low-skilled labour. Second, if the low-skilled labour market is unionized, we find that a stimulation of outsourcing raises both relative wages and relative employment of high-skilled labour in Home.

In the empirical application, we focus on outsourcing by Austrian manufacturing industries and find that our theoretical predictions are widely in accordance with the empirical results. Outsourcing to Eastern countries is low-wage seeking. Moreover, shrinking trade barriers are an important stimulus of outsourcing to the Central and Eastern European countries and the former Soviet Union. Regarding the labour market effects in Austria, we estimate the impact of outsourcing on relative employment, controlling for other non-neutral influences. We find that a $1 \%$ increase in outsourcing to the Eastern countries relative to gross production induces a shift in relative employment by about $0.1 \%$ in favour of high-skilled labour. Outsourcing to the Eastern economies accounts for about one quarter of the change in relative employment in favour of high-skilled labour in the last decade. This phenomenon could prove to be similar for some of the other small Western European countries and it is likely to become even more pronounced, when (some of) the Eastern economies join the European Union.

\section{Acknowledgements}

We wish to thank Sven Arndt, Josef Baumgartner, Fritz Breuss, Josef Falkinger, Jayalakshmi Krishnakumar, László Mátyás, Michael Pfaffermayr, Rudolf Winter-Ebmer, and two anonymous referees for helpful discussions and suggestions. We have also benefited from discussions at the University of Linz economics department research seminar, seminars at the Vienna Institute for Comparative Economic Studies and the Austrian Institute of Economic Research, and the annual meeting of the Austrian Economic Association. 
We are indebted in Wilhelm Kohler, Karl Schwarz, the Austrian Trade Union Federation, and the Vienna Institute for Comparative Economic Studies for the provision of data.

\section{References}

Arndt, S.W. (1997). 'Globalisation and the open economy', North American Journal of Economics and Finance, 8, 71-9.

Arndt, S.W. (1999). 'Globalisation and economic development', Journal of International Trade and Economic Development, 8, 309-18.

Belman, D. and Heywood, J.S. (1990). 'Union membership, union organization and the dispersion of wages', Review of Economics and Statistics, 72, 148-53.

Berman, E., Bound, J., and Griliches, Z. (1994). 'Changes in the demand for skilled labour within US manufacturing: evidence from the annual survey of manufactures', Quarterly Journal of Economics, 109, 367-97.

Burda, M.C. and Dluhosch, B. (2002). 'Cost competition, fragmentation and globalization', Review of International Economics, 10, 424-41.

Buse, A. (1992). 'The bias of instrumental variable estimators', Econometrica, 60, 173-80.

Davidson, R. and MacKinnon, J.G. (1993). Estimation and Inference in Econometrics, Oxford University Press, Oxford.

Deardorff, A.V. (2001). 'Fragmentation in simple trade models', North American Journal of Economics and Finance, 12, 121-37.

Dell'Aringa, C. and Lucifora, C. (1994). 'Wage dispersion and unionism: do unions protect low pay?', International Journal of Manpower, 15, 150-69.

Egger, H. (2002). 'International outsourcing in a two-sector Heckscher-Ohlin model', Journal of Economic Integration, 17, 687-709.

Egger, H. and Egger, P. (2001). 'Cross-border sourcing and outward processing in EU manufacturing', North American Journal of Economics and Finance, 12, 243-56.

Egger, H. and Egger, P. (2002). 'How international outsourcing drives up Eastern European wages', Weltwirtschaftliches Archiv, 138, 83-96.

Egger, H. and Falkinger, J. (2001). 'A complete characterization of the distributional effects of international outsourcing in the Heckscher-Ohlin Model', Working Paper No. 573, CESifo, Munich.

Feenstra, R.C. (1998). 'Integration of trade and disintegration of production in the global economy', Journal of Economic Perspectives, 12, 31-50.

Feenstra, R.C. and Hanson, G.H. (1996). 'Globalisation, outsourcing, and wage inequality', American Economic Review: Papers and Proceedings, 86, 240-5.

Feenstra, R.C. and Hanson, G.H. (1997). 'Productivity measurement and the impact of trade and technology on wages: estimates for the US, 1972-1990', Working Paper No. 6052, NBER, Cambridge, MA.

Feenstra, R.C. and Hanson, G.H. (1999). 'The impact of outsourcing and high-technology capital on wages: estimates for the United States, 1979-1990', Quarterly Journal of Economics, 114, 907-40.

Feenstra, R.C. and Hanson, G.H. (2001). 'Global production sharing and rising inequality: a survey of trade and wages', in K. Choi and J. Harrigan (eds.). Handbook of International Trade, Basil Blackwell, Oxford, forthcoming. 
Görg, H. (2000). 'Fragmentation and trade: US inward processing trade in the EU', Weltwirtschaftliches Archiv, 136, 403-22.

Greenaway, D., Hine, R.C., and Wright, P. (1999). 'An empirical assessment of the impact of trade on employment in the United Kingdom', European Journal of Political Economy, 15, 485-500.

Greene, W.H. (1997). Econometric Analysis, 3rd edition, Prentice Hall, London.

Grossman, G.M. and Helpman, E. (2002). 'Integration versus outsourcing in industry equilibrium', Quarterly Journal of Economics, 117, 85-120.

Hausman, J. (1978). 'Specification tests in econometrics', Econometrica, 46, 1251-71.

Jones, R.W. (2000). Globalization and the Theory of Input Trade, MIT Press, Cambridge, MA.

Jones, R.W. and Kierzkowski, H. (1990). 'The role of services in production and international trade: a theoretical framework', in R. W. Jones and A. O. Krueger (eds), The Political Economy of International Trade: Essays in Honor of Robert E. Baldwin, Blackwell, Oxford, 31-48.

Jones, R.W. and Kierzkowski, H. (2001). 'Globalization and the consequences of international fragmentation', in R. Dornbusch, G. Calvo and M. Obstfeld (eds.). Festschrift in Honor of Robert Mundell, MIT Press, Cambridge, MA.

Kohler, W. (2001). 'A specific-factors view on outsourcing', North American Journal of Economics and Finance, 12, 31-53.

Krishnakumar, J. (1996). 'Simultaneous equations', in L. Mátyás and P. Sevestre (eds.). The Econometrics of Panel Data. A Handbook of the Theory with Applications, $2^{\text {nd }}$ edition, Kluwer, Dordrecht, 196-235.

Krugman, P.R. (1995). 'Growing world trade: causes and consequences', Brookings Papers on Economic Activity, I, 327-77.

Krugman, P.R. (2000). 'Technology, trade and factor prices', Journal of International Economics, 50, 51-71.

Leamer, E. (1998). 'In search of Stolper-Samuelson linkages between international trade and lower wages', in S. Collins (ed.). Imports, Exports and the American Worker, Brookings Institution, Washington, DC, 142-202.

Meng, R.A. (1990). 'Union effects on wage dispersion in Canadian industry', Economics Letters, 32, 399-403.

Royston, P. (1991). 'Shapiro-Wilk and Shapiro-Francia tests', Stata Technical Bulletin, 3, reprinted in Stata Technical Bulletin Reprints, 1, 105.

Shea, J. (1997). 'Instrument relevance in multivariate linear models: a simple measure', Review of Economics and Statistics, 79, 348-52.

Slaughter, M. J. (2000). 'Production transfer within multinational enterprises and American wages', Journal of International Economics, 50, 449-72.

\section{Appendix: data description}

\section{A.1 Trade data}

Data on final and intermediate goods exports and imports are from Statistics Austria. Contrary to Feenstra and Hanson, who used a wide measure of outsourcing including 'all imported intermediate or final goods that are used of, or sold under the brandname 
of, an American firm' (Feenstra and Hanson, 1996, p.107), we apply a narrow one, including only intermediate goods imported from Eastern countries, which are produced by industry $i$ firms abroad and used by firms of the same industry classification in Austria.

Since data on cross-border outsourcing are not directly available, we construct a measure for the volume of outsourcing to Eastern countries in the following way

$$
O_{i t}=\underbrace{\left(\text { intermediates }_{i i t}\right)}_{A} \underbrace{\left(\frac{\text { imports }_{i t}^{\text {World }}}{\text { gross production }_{i t}}\right)}_{B} \underbrace{\left(\frac{\text { imports }_{i t}^{\text {Eastern countries }}}{\text { imports }_{i t}^{\text {world }}}\right)}_{C}
$$

The first term $(A)$ comprises the total volume of national and international outsourcing of industry $i$, i.e., intermediate goods purchases of industry $i$ firms from domestic and foreign suppliers of the same industry classification $i$ at time $t$. To obtain the volume of outsourcing to Eastern countries $A$ is weighted by $B \cdot C$. Term $B$ represents overall intermediate and final goods imports of industry $i$ relative to gross production of industry $i$, i.e., import openness of industry $i$. Term $C$ measures the share of imports from Eastern countries in overall imports. $(A \cdot B)$ for 1990 is reported in Austrian Input-Output statistics. For 1995 only $A$ and for 2000 a preliminary estimate of $(A \cdot B)$ are available. We collect the remaining information $(B, C)$ at an annual basis from trade and industry statistics over the period 1990-1998 and interpolate $A$ for the missing years.

In the econometric analysis below, we use two specifications for outsourcing to Eastern economies. First, the volume of cross-border outsourcing of sector $i\left(O_{i t}\right)$ relative to gross production of industry $i$, referred to as $O Y$, and, second, the volume of cross-border outsourcing of sector $i\left(O_{i t}\right)$ relative to overall intermediate goods imports of sector $i$, referred to as $O I .{ }^{17}$ A change in $O Y$ comprises two effects: (i) the change of overall national and international outsourcing relative to gross production and (ii) the change in the share of intermediate goods imports from the Eastern countries in total intermediate goods imports. ${ }^{18}$ According to (14), we always concentrate on intermediate goods purchases by industry $i$ firms from suppliers of the same industry classification $i$ abroad. In contrast, $O I$ only comprises (ii), i.e., the share of Eastern countries in overall intermediate goods imports.

Trade barriers (the applied most-favoured-nation tariff rate, $T B$, and the frequency ratios of non-tariff barriers, NTB) are from OECD and UNCTAD statistics. Data again were interpolated and reclassified to the NACE 2-digit level. NTB tables report zero frequency for a few industries (years), and natural numbers otherwise. Therefore, we must not simply take logs. Rather, we construct a dummy variable (NTBD), indicating whether $N T B$ s are applied $(N T B D=1)$ or not $(N T B D=0)$. We construct a variable $N T B I$, which takes the $\log$ of $N T B$, if $N T B D=1$, i.e., if non-tariff barriers are applied. Otherwise, we set NTBI at zero. The parameter of NTBI can only be interpreted together with NTBD. All trade barrier variables $(T B, N T B D, N T B I)$ exhibit variation in both the industry and time dimensions.

\footnotetext{
${ }^{17}$ Overall intermediate goods imports of sector $i$ are measured by (intermediates ${ }_{i t}$ ) $\left(\right.$ (imports $_{i t}^{\text {world }}$ / gross production $_{i t}$ ), where intermediates ${ }_{i t}$ are all national and international intermediate goods purchases of firms in industry classification $i$.

${ }^{18}$ Note that $O Y$ can also be written as $O Y_{i t}=\left(\right.$ intermediates $_{i t} /$ gross production $\left._{i t}\right)$ (intermediates $_{i i t} /$ intermediates ${ }_{i t}$ ), where intermediates $s_{i t}$ are all national and international intermediate goods purchases of firms in industry classification $i$.
} 


\section{A.2 Skill and union data}

We collect information regarding skills (employment and wages) from the Austrian 'Lohn und Gehaltsstatistik' provided by the Austrian Chamber of Commerce, which is available for industry categories similar to NACE. These statistics classify employees according to their utilization and not according to their education or training. We define the sum of workers with jobs requiring a high/special qualification level as high-skilled workers. The remaining employees are classified as low-skilled.

Data on union membership were provided by various sections of the Austrian Trade Union Confederation, which is a centrally managed organization. These sections cover either one or more industries and bargain over wages for the respective groups of workers. We measure the degree of organization of an industry by the variable

$$
O R G_{i t}=\frac{{\text { unionization } \text { rate }_{i t}}_{\text {unionization } \text { rate }_{t}}}{\text { unions }}
$$

i.e., by the degree of unionization of industry $i$ relative to the average industry in each year $t$. ORG varies over 11 groups of industries due to the organization of the Austrian Trade Union Federation.

\section{A.3 Remaining variables}

Median firm size (MSIZE) and price-cost margins (PCM) are additional variables, which may be relevant for the power of employees in wage bargaining. Median firm size is available from the monthly WIFO investment survey of Austrian manufacturing firms (NACE 2-digit). The price-cost margin variable is measured as the share of value added minus wage costs in gross production. Information on gross production, value added, nominal capital stocks, and capital deflators (all NACE 2-digit) is provided by Statistics Austria. The percentage of hours of capital stock in use is also reported in the WIFO investment survey.

Finally, unit labour costs of seven Eastern economies (Bulgaria, Czech Republic, Hungary, Poland, Romania, Slovak Republic, Slovenia) at the industry level are derived from employment, wage, and gross production data (including production indices), which were provided by the Vienna Institute for Comparative Economic Studies (WIIW). These data are reported in ISIC classification and in own currency. We use 1993 as the base year, and convert the series according to the fixed exchange rate (1993) and aggregate them using industry-specific real gross production of the respective Eastern country as the weight. We apply the resulting variable as an approximate measure of unit labour costs for the Eastern countries as a whole (ULCE), including Central and Eastern Europe and the former Soviet Union. 